\title{
EGFR NP_005219.2:p.H773_V774insGH
}

National Cancer Institute

\section{Source}

National Cancer Institute. EGFR NP 005219.2:p.H773 V774insGH. NCI Thesaurus. Code C98685.

An insertion of the amino acid sequence glycine-histidine between the histidine at position 773 and the valine at position 774 of the epidermal growth factor receptor protein. 